TÜRK FEN EĞİTIMİ DERGISİ

Yıl 17, Sayı 1, Mart 2020

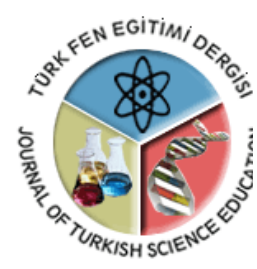

http://www.tused.org
TURKISH SCIENCE EDUCATION

Volume 17, Issue 1, March 2020

\title{
The Effect of STEM Project Based Learning on Self-Efficacy among High-School Physics Students
}

\author{
Mohd Ali SAMSUDIN ${ }^{1}$, Seyedh Mahboobeh JAMALI ${ }^{2}$, Ahmad Nurulazam MD ZAIN ${ }^{2}$, \\ Nader ALE EBRAHIM ${ }^{4}$
}

\begin{abstract}
${ }^{1}$ Assoc. Prof. Dr. School of Educational Studies (PPIP), Universiti Sains Malaysia, Penang, Malaysia, ORCID ID: 0000-0001-8231-5775

${ }^{2}$ Researcher, Dr., Eshragh Institute, Ministry of Education district 7, Tehran, Iran, and School of Educational Studies (PPIP), Universiti Sains Malaysia, Penang, Malaysia, ORCID ID: 0000-0001-8728-5827

${ }^{3}$ Prof. Dr. School of Educational Studies (PPIP), Universiti Sains Malaysia, Penang, Malaysia, ORCID ID: 0000-0001-5399-2355

4 Adjunct Lecturer, Dr., Research and Technology Department, Alzahra University, Vanak, Tehran, Iran, ORCID ID: 0000-0001-7091-4439
\end{abstract}
Received: 24.05 .2018
Revised: 17.08 .2018
Accepted: 16.10 .2018

The original language of article is English (v.17, n.1, March 2020, pp.94-108, doi: 10.36681/tused.2020.15)

Reference: Samsudin, M. A., Jamali, S. M., Zain, A. N. M., \& Ale Ebrahim, N. (2020). The Effect of STEM Project Based Learning on Self-Efficacy among High-School Physics Students. Journal of Turkish Science Education, 17 (1), 94-108.

\begin{abstract}
Science, Technology, Engineering and Mathematics (STEM) Project-Based Learning (PjBL) is increase effectiveness, create meaningful learning and influence student attitudes in future career pursuit. There are several studies in the literature reporting different aspects of STEM into a PjBL pedagogy. However, the effect of implementing STEM PjBL in terms of improving students' skills in self-efficacy levels in physics mechanics at high school level has not been demonstrated as expected in the previous literature. This study followed a quasi-experimental research method. Bandura's social cognitive theory is used to assess and compare the effect of STEM PjBL with conventional teaching method on students' selfefficacy level in learning physics among over 100 high school students. The result illustrated that STEM $\mathrm{PjBL}$ improve students' self-efficacy to solve physics problem. Also, the study proposes a guideline for future research.
\end{abstract}

Keywords: Project-Based learning (PjBL), science, technology, engineering and mathematics (STEM), physics education, problem-solving, bibliometrics, performance evaluation.

\section{INTRODUCTION}

Students are more likely to engage in activities that they feel efficacious. In other words, students need and like to have self-efficacy for learning material before they engage in strategic effort (Doordinejad \& Afshar, 2014). When students have high self-efficacy, they 
feel that they will be successful in tasks (Jamali et al., 2017). As Pintrich and de Groot (1990) reported, students with high self-efficacy tend to persist more toward achieving their goals. In addition, it was reported that self-efficacy is one of the strong predictors of academic performance (Bandura, 1997; Doordinejad \& Afshar, 2014; Wigfield, 1994). Some studies supported that students in a learning environment embedded with real-life issues tend to exhibit positive self-efficacy beliefs on curriculum subject (Hampton \& Mason, 2003; Jungert et al., 2014). Furthermore, as Linnenbrink and Pintrich (2003) stated for meaningful learning and improved self-efficacy, students should be engaged in learning process in terms of cognitive and behavioral aspects. Other researchers also found that STEM PjBL increase effectiveness and encourages meaningful learning through student directed investigation (Blumenfeld et al., 1991; Olivarez, 2012; Tseng et al., 2013; Vega et al., 2013).

Directly and indirectly, self-efficacy showed powerful correlations between academic performance and personal adjustment (Jamali et al., 2015; Samsudin et al., 2017). Students who had confidence when entering college performed significantly better during their first year than students who had less confidence (Chemers et al., 2001; Varon, 2015). Bandura (1997) has argued that self-efficacy leads to set higher goals and achieving higher goals increase the positive effects of self-efficacy by providing an evaluative context to aid selfregulation. In order to pursue deeper learning for students, $\mathrm{PjBL}$ has emerged as a comprehensive approach to classroom teaching and learning that is designed to engage students in investigation of authentic problems (Blumenfeld et al., 1991). Varon (2015) defined that students engaged in engineering design process and other STEM related projects should also develop self-efficacy. Instead of giving up on projects that they presented with, they should learn how to see each project as a challenge and persevere while using problem solving to successfully meet those challenges. There are several studies in the literature reporting different aspects of STEM into a PjBL pedagogy (Frank et al., 2003; Gardiner, 2014; Lou et al., 2011; Olivarez, 2012; Vega et al., 2013). Marginson et al. (2013) identified the cultural capital invested in families with STEM connections that act to set high standards towards achievement in science or mathematics, provide role models for interest and work in STEM, and increase students' self-efficacy in relation with STEM subjects (Blenkinsop et al., 2006; Lyons, 2005). However, the effect of STEM PjBL on self-efficacy has still undiscovered among high-school physics students. So, the aim of this paper was to cover the research gap through using Bandura's social cognitive theory to compare the effect of STEM $\mathrm{PjBL}$ with conventional teaching method on students' self-efficacy level in learning physics.

\section{LITERATURE REVIEW}

STEM PjBL is an approach leading students to explore ill-defined problems which integrate STEM within a constrained environment. Student-centered approach, hands-on activities, promoting collaboration, team communication, knowledge construction, and having a formative assessment have been indicated as primary components of STEM PjBL. By involving students in solving real world projects, working in collaborative groups, applying scientific reasoning, and developing real solutions, current research in STEM PjBL suggests that learning activities may increase student achievement in STEM fields (Fortus et al., 2005).

According to Kelly (2015), Bandura's social cognitive theory explores the ways in which cognitive, behavioral, personal, and environmental factors interact and determine motivation and behavior. Social cognitive theory suggests that parts of an individual's knowledge acquisition are influenced by social interactions, social observation, outside influences (media, etc.), and experience (Bandura, 1989; Bardach et al., 2010). Bandura's social cognitive theory suggests that students who perceived a low self-efficacy towards their ability are unlikely to grow and expand their skills. Self-efficacy is identified as a personal 
factor of social cognitive theory and refers to a person's confidence in his or her ability to gather the required intrinsic resources necessary for successful task completion (Skaalvik \& Skaalvik, 2007). The identification of self-efficacy as a personal factor within social cognitive theory is further supported by Bandura's characterization and reference to self-efficacy as "people's judgments of their capabilities" (Bandura, 1986).

Bandura (1997) defined four self-efficacy sources for the extension of these beliefs (Pleiss et al., 2012; Sawtelle, 2011):

- Mastery Experiences (ME) differentiate the experiences which have successful results through having a strong relation with high self-efficacy and experiences which have negative results connected to low self-efficacy.

- Vicarious Experiences (VE) happens when individuals watch others and compares themselves to them regarding their task.

- Social Persuasions (SP) are verbal suggestions from others, often relating to stereotypes or biases.

- Physiological States (PS) are physical and emotional responses - such as anxiety or stress- encountered while attempting a task.

Bandura (1977) hypothesized that expectations of self-efficacy would affect the amount of effort performed by an individual into a task, and duration of the effort especially in the face of other obstacles that may arise. The self-efficacy literature also links student's science self-efficacy to persistence in science majors and career choices in science (Britner \& Pajares, 2006; Dalgety \& Coll, 2006), and achievement in science for high school students (Bøe et al., 2011; Lau \& Roeser, 2002). The aim of this study is to indicate whether the development of self-efficacy that occur in STEM PjBL can lead to perform better problem solver in the physics mechanics test for high school students.

\section{a) STEM PjBL and Self efficacy}

Varon (2015) indicated that self-efficacy along with other cognitive factors is very important to the educational and vocational behavior of students considering careers in engineering and science fields. It was defined as "beliefs in one's capabilities to organize and execute courses of action required to produce given attainments" (Bandura, 1997). Cervantes (2013) mentioned that academic programs like STEM PjBL are innovative in nature because they concentrate on developing critical thinkers by engaging students in more authentic learning that requires solving real-world problems, collaboration, extensive research, inquiry, writing, analysis, and effective communication (Newmann, 1996). As Darling-Hammond et al. (2008) noted, students learn at deeper levels and perform better on complex tasks by engaging in authentic projects that draws subject knowledge to solve real-world problems (Cervantes, 2013).

Overall, According to Han et al. (2014) students who have experienced STEM PjBL showed positive attitudes toward learning itself, team communication, and collaborative behavior (Dominguez \& Jaime, 2010; Rooij, 2009; Veenman et al., 2000). In addition, STEM $\mathrm{PjBL}$ was examined with respect to increasing students' interest, self-confidence, and selfefficacy (Baran \& Maskan, 2010), which was highly related to the components of STEM $\mathrm{PjBL}$ such as collaborations in group work and contextual problems reflecting students' real world experiences. In addition, students who studied in STEM PjBL classrooms were less likely to drop out of courses and school (Dominguez \& Jaime, 2010; Han et al., 2014). 


\section{b) Theoretical framework}

The first development of self-efficacy is an essential part of the theoretical framework in the attempt to explain and understand change of behaviors (Bandura, 1997). One definition of self-efficacy is the possessed confidence of an individual in themselves to perform a certain task. The first research into self-efficacy frameworks focused on behavioral changes in people who suffered from severe phobias (Bandura, 1997; Lent et al., 1996). Another definition refers to it as a personal factor of social cognitive theory and the confidence, an individual has in his or her ability to obtain the necessary resources to complete a task successfully (Skaalvik \& Skaalvik, 2007). In social cognitive theory, selfefficacy is deemed to be one of its critical component (Bandura et al., 2001; Betz \& Hackett, 2006; Klassen, 2004). The social cognitive theory postulates that people are agents that intentionally change the world around them (Clark, 2014). As a learning theory, social cognitive theory suggests that some parts of the knowledge acquired by someone can have direct relations with observation of others in social interactions, experiences and influence of the media (Bardach et al., 2010; Kelly, 2015).

STEM PjBL allow students to learn in groups, observe others while doing their own STEM projects, learn from their peers. The group work of STEM PjBL is aligned with social cognitive theory (Erdogan et al., 2016) which has direct relations with observation of others activities in social interactions and experiences (Han, 2017). In STEM PjBL, students have to follow several phases which define the problem from developing and testing the product in order to improve the product. Consequently, the phases allow the students to systematically monitor their process while the teacher as a facilitator gives them feedback continuously.

When Bandura (1977) drew the framework of social cognitive theory in order to explain behavioral change, he came up with self-efficacy as one of its major components and discussed what types of experiences help to build up self-efficacy as well. According to his theory, there are four categories of these experiences (Bandura, 1997). The categories are included: mastery experiences, vicarious learning experiences, social persuasion experiences, and the physiological state. There is widespread research on the impact of self-efficacy on achievement while the studies on the effect of STEM PjBL on self-efficacy among secondary school students are less extensive.

\section{c) Self-efficacy Publication trends}

The results of bibliometric analysis (like publication trends) can shed light on factors that strengthen the contribution of studies in a research area and guide scholars towards producing impactful studies (Akhavan et al., 2016). In such evaluations, the number of papers published and the number of citations received that represent two of the most important indicators of an impactful contribution (Amoozegar et al., 2018; Jamali et al., 2015). In general, there is a significant positive relationship between the number of citations that a paper receives and the general perception with regard to its quality (Marks, 2001). A title search of "self-efficacy" on the Web of Science Database (formally known as ISI Web of Knowledge) revealed 9,194 documents in which 1,221 of them belongs to "Education and Educational Research" category. Out of 1,221 documents only 9 of them were relevant to the "Project Based Learning" (PjBL). Therefore, a few research has been done on the relationship between the self-efficacy and PjBL. Table 1 shows a list of nine documents relevant to PjBL and Self-Efficacy in the "Education and Educational Research" category of Web of Science Database. None of them investigated the effect of STEM PjBL on self-efficacy among highschool physics students. Figure 1 shows the trend of citations in each year on the 9,194 
documents relevant to "Self-Efficacy" (Data retrieved from Web of Science Databases on 29 April 2017 from University of Malaya access point). The citations trends increased dramatically within past 20 years. It means that the number of recent publications on the title of "Self-Efficacy" referred to previous documents are quite noticeable. So, the researchers are interested to the "Self-Efficacy" issue in the "Education and Educational Research" category.

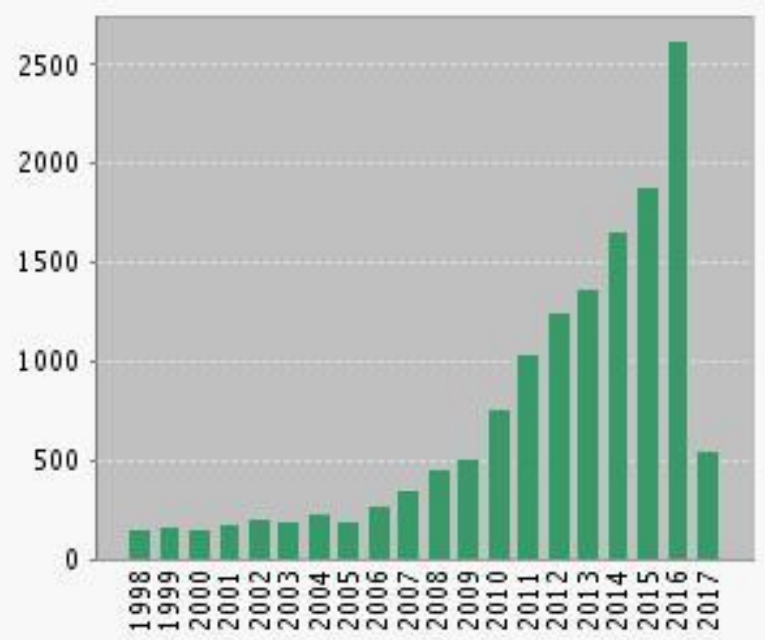

Figure 1. Trend of citations in each year on the 9,194 documents relevant to "Self-Efficacy" (Data retrieved from Web of Science Database on 29 April 2017 from University of Malaya access point)

Table 1. List of nine documents relevant to PjBL and Self-Efficacy in the "Education and Educational Research" category of Web of Science database

\begin{tabular}{|c|c|c|c|}
\hline No. & Document title & Source & References \\
\hline & $\begin{array}{l}\text { Development of an Evidence-based Professional } \\
\text { Learning Program Informed by Online Teachers' } \\
\text { Self-efficacy and Threshold Concepts }\end{array}$ & Online Learning & $\begin{array}{l}\text { (Gosselin et al., } \\
\text { 2016) }\end{array}$ \\
\hline & The Effects of Project Based Learning on & Eurasia Journal of Mathematics & \\
\hline & Undergraduate Students' Achievement and Self- & Science and Technology & 2015) \\
\hline & $\begin{array}{l}\text { Enhancing students' self-efficacy in making } \\
\text { positive career decisions }\end{array}$ & $\begin{array}{l}\text { Asia-Pacific Journal of } \\
\text { Cooperative Education }\end{array}$ & (Reddan, 2015) \\
\hline & $\begin{array}{l}\text { The investigation of STEM Self-Efficacy and } \\
\text { Professional Commitment to Engineering among } \\
\text { female high school students }\end{array}$ & $\begin{array}{l}\text { South African Journal of } \\
\text { Education }\end{array}$ & (Liu et al., 2014) \\
\hline & $\begin{array}{l}\text { Evaluation of Impact of Web-based Activities on } \\
\text { Mechanics Achievement and Self-Efficacy }\end{array}$ & 2014 ASEE Annual Conference & $\begin{array}{l}\text { (Billington et al., } \\
\text { 2014) }\end{array}$ \\
\hline & Self-Efficacy for Cross-Disciplinary Learning in & Journal of Engineering & (Schaffer et al., \\
\hline & Project-Based Teams & Education & 2012) \\
\hline & $\begin{array}{l}\text { A Guide du Routard Simulation: Increasing Self- } \\
\text { Efficacy in the Standards Through Project-Based } \\
\text { Learning }\end{array}$ & Foreign Language Annals & (Mills, 2009) \\
\hline & $\begin{array}{l}\text { The development of a college biology self- } \\
\text { efficacy instrument for nonmajors }\end{array}$ & Science Education & $\begin{array}{l}\text { (Baldwin et al., } \\
\text { 1999) }\end{array}$ \\
\hline & $\begin{array}{l}\text { A qualitative study of factors influencing science } \\
\text { teaching self-efficacy of elementary level } \\
\text { teachers }\end{array}$ & Science Education & $\begin{array}{l}\text { (RameyGassert } \\
\text { et al., 1996) }\end{array}$ \\
\hline
\end{tabular}

This study examined the following research question: 
Q1: Is there any significant difference on the linear combination of post-test mean scores of self-efficacies in learning physics between students who follow STEM PjBL and conventional teaching method after the effect of mean scores of pre-test is controlled?

\section{MATERIALS and METHODS}

The purpose of this study is to compare the effect of Science, Technology, Engineering and Mathematics (STEM) Project-Based Learning (PjBL) and conventional teaching on selfefficacy in learning mechanic physics, among high school physics students. So, a quasiexperimental research method was followed in this study because the experimental design do not utilize random assignment of participants to groups, there is greater likelihood that extraneous variables (variables that are not the focus of the study that cause confusion to occur when researchers consider the relationships between variables being studied) may impact a study's findings (Slavin, 2007). The style of this study is nonequivalent control to evaluate the effect of STEM PjBL. The sample contained of two groups of the physics high school students. The first experimental group was used STEM PjBL method. And, the second group is a control group and used conventional teaching method. In order to avoid any contamination between experimental and control groups, groups are selected from different schools with the same level of teaching and performance quality. In this selection procedure, the school environments and the instructor's level remained the same. A questionnaire consists of 33 items of self-efficacy in learning physics are administered to whole groups before and after the interventions. The test questionnaire on self-efficacy skills is developed based on the team work skills questionnaire by (Bandura, 1977; Fencl \& Scheel, 2005; Sawtelle, 2011). The items of self-efficacy skills questionnaire are adapted with minor changes based on the Malaysian high school students' environment. So, it's become suitable to a new application or recent situation, and to improve items condition to become relevant to high school environment.

The population in the study consisted of students in Physics course in $10^{\text {th }}$ grade Malaysian and international high schools in Malaysia. Students were $10^{\text {th }}$ grade high schools in the academic year 2016-2017 who have mechanic subject in Physics including the pulley system and the simple pendulum. The sample of this study consists of high school students in eight classes from different schools who are selected from a population of 12 classes including 120 students in Physics course in $10^{\text {th }}$ grade Malaysian and international high school in Malaysia. Both of the conventional and interventional groups are taught by the same level of instructor (experienced teacher with high quality performance in teaching mechanic subject in Physics). One of the two of the classes with the highest number of students are randomly chosen as the experimental group $(\mathrm{N}=50)$ which is instructed with STEM PjBL method and the other class is also randomly chosen as the control group $(\mathrm{N}=57)$ which is instructed on the same topic through the use of a conventional teaching method.

The maximum score of test questionnaire on self-efficacy skills is 5 marks per response on options of each item, the self-efficacy skills questionnaire consists of 33 items gathered in four self-efficacy sources as Bandura (1977) defined and recently used by Pleiss et al. (2012); Sawtelle (2011). These four self-efficacy sources consist of Mastery Experiences (ME), Vicarious Experiences (VE), Social Persuasions (SP), and Physiological States (PS). The scale of scores for each questionnaire is according to Likert scale which starts from 1 to 5 marks. The mark 1 is given for option "strongly disagree" and 5 marks for option "strongly agree". Table 2 shows four componets of self-efficacy questionaaire and its relevant normal/reservse scored questions. 
Table 2. Four components of self-efficacy questionnaire

\begin{tabular}{lllll}
\hline Items & $\begin{array}{l}\text { Mastery } \\
\text { Experiences (ME) } \\
\mathbf{1 0 ~ I t e m s}\end{array}$ & $\begin{array}{l}\text { Vicarious } \\
\text { Experiences (VE) } \\
\text { 7 Items }\end{array}$ & $\begin{array}{l}\text { Social Persuasions } \\
\text { (SP) } \\
\text { 7 Items }\end{array}$ & $\begin{array}{l}\text { Physiological } \\
\text { States (PS) } \\
\text { 9 Items }\end{array}$ \\
\hline $\begin{array}{l}\text { Normal scored } \\
\text { items }\end{array}$ & $1,4,22,30,33$ & $10,19,23,27$ & $5,12,16,20,32$ & $6,9,13,24,26$ \\
$\begin{array}{l}\text { Reverse scored } \\
\text { items }\end{array}$ & $8,11,14,15,17$ & $3,7,31$ & 25,28, & $2,18,21,29$ \\
Total score (165) & 50 & 35 & 35 & 45 \\
\hline
\end{tabular}

To examine the main research question and hypothesis of this study, the inferential method including multivariate analysis of covariance (MANCOVA) followed by Bonferroni test for mean comparison between experimental and control group. The data normality was assessed before to run the MANCOVA analysis. Participants with different characteristics in the experimental and control groups may has different effects on the dependent variable. The MANCOVA technique eliminate the effect of different participants' characteristics. All data were distributed normally by checking each item's Skewness and Kurtosis as well as inspecting the shape of the data distribution by using histogram curve.

\section{a) The STEM Project}

The full name of the project was design $\&$ build a pulley system. Students started with exploring building process of a crane and the simple machine named a pulley system. Then they learned about the usage of pulley to change the direction of applied forces, move or lift extremely heavy objects and the mechanical advantages associated with use of multiplepulley system. Subsequently, they performed a simple demonstration to gauge mechanical advantages of using a pulley and identified how pulleys are applied in modern day engineering. during a hands-on activity. They observed how a pulley could change the direction of a force, the difference between fixed and movable pulleys, and the mechanical advantage obtained through multiple or combined pulleys. They also observed how pulleys were used by engineers for everyday purposes and the ways to use them.

In this activity, students were given an opportunity to experience the mechanical advantages of pulleys first-hand. They were given a challenge to help lifting a heavy object to the roof and they went back to the various pulleys that they learned about lifting the object. Students worked on their own and as part of a group to build a crane that could be used to pick up pieces of metal or a heavy box. Then, they tested different pulley systems and examined the closeness of the theoretical advantage to the actual experience. Subsequently, they were going to test the calculations that they made for the mechanical advantage of the pulleys and learned whether the calculations were reliable predictors of what actually happens in the real world.

In the project, instructor focused on the use of STEM PjBL method for teaching the simple machine principles and mechanical advantages of pulley system. Therefore, students learned about the objectives of running the pulley project which were as follow:

- How pulleys are useful in daily life?

- How pulleys make work easer for engineers?

- Teamwork and problem solving;

- Technology in the design and product process of a crane;

- Mathematics in real world like how to measure the force and mechanical advantages;

- How to think like an engineer to test and retest the product?

- Analyzing and synthesis of the collected data during the project. 
The systematic approach provided by the nature of engineering design helps students in solving problems as regularly occur in STEM projects (Kelley \& Knowles, 2016). Running the pulley project created an opportunity for students to involve in design, engineering, production, and research procedure in a group work setting which improve their self-efficacy.

\section{RESULTS}

A comparison of self-efficacy post-test results in terms of four subscales which are consists of: Mastery Experiences (ME), Vicarious Experiences (VE), Social Persuasions (SP), and Physiological States (PS) is shown in Figure 2. The mean score comparison between experimental and control groups in terms of four subscale of self-efficacy is displayed in Figure 3.

Mastery Experiences (ME)
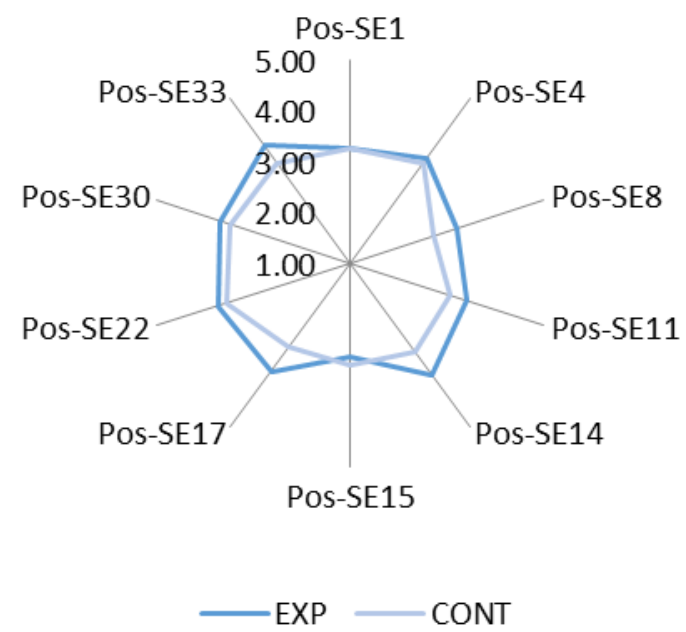

Social Persuasions (SP)

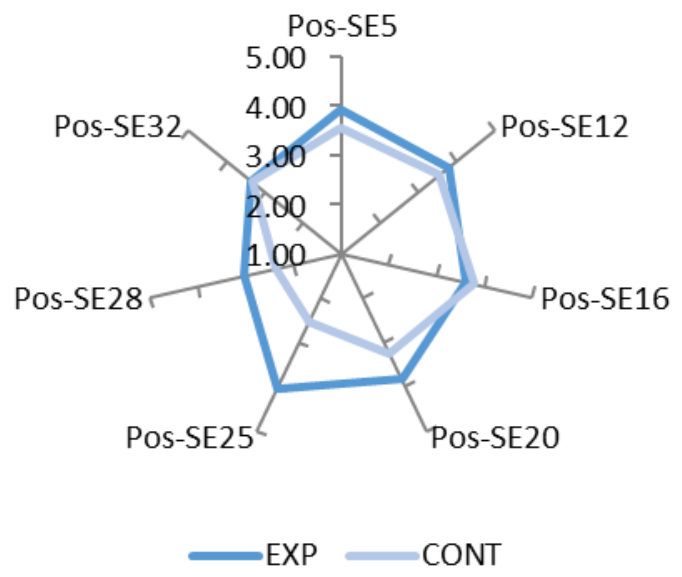

Vicarious Experiences (VE)

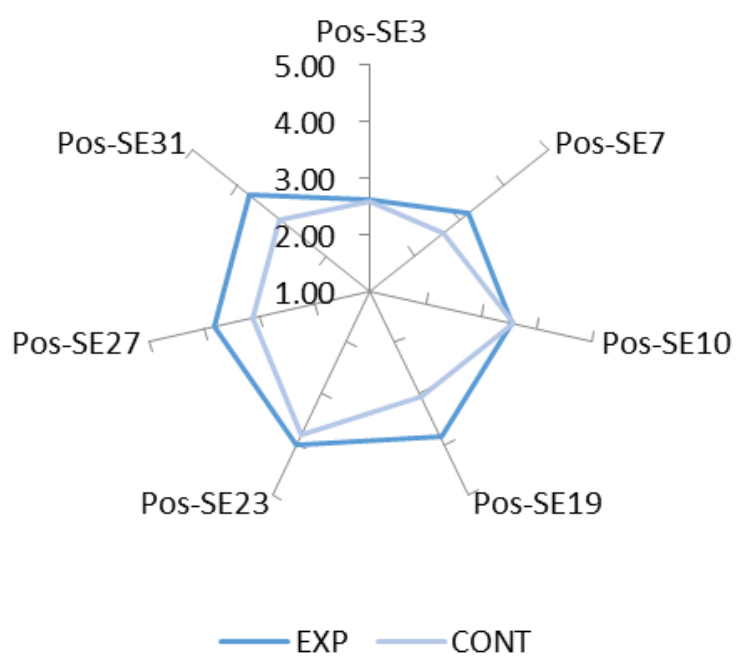

Physiological States (PS)

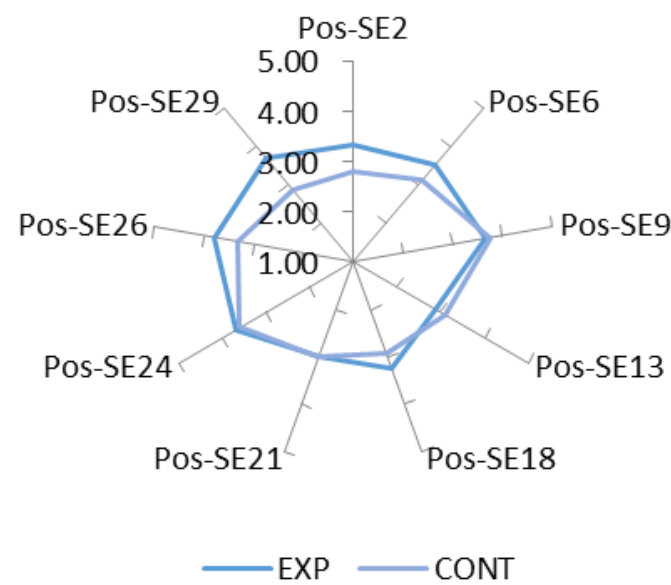

Figure 2. A comparison between experimental and control groups $(1=$ Strongly Disagree $\& 5$ $=$ Strongly Agree) 


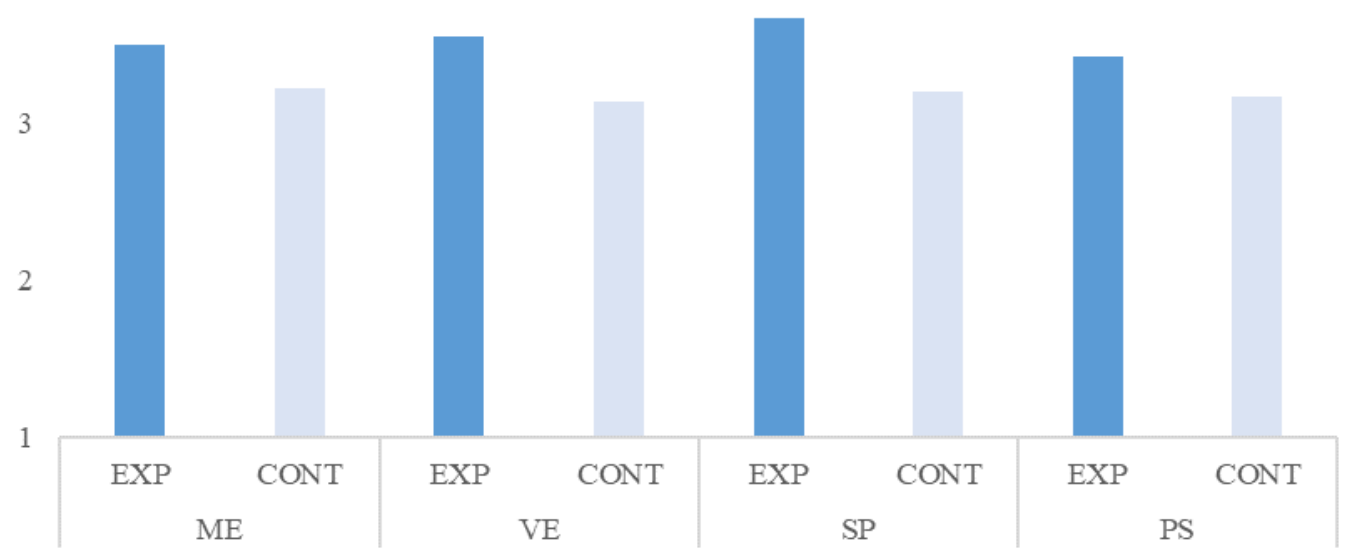

Figure 3. The mean score comparison between experimental and control groups $(1=$ Strongly Disagree \& $5=$ Strongly Agree) in terms of four subscale of self-efficacy

Table 3 shows the mean score differences between experimental and control groups in the post self-efficacy results. So, the mean score difference for the post-test results of selfefficacy between experimental and control group is $(3.53-3.18=0.35)$ which equal to $11 \%$ improvements (compare to the control group mean score). The self-efficacy score was a 5points Likert scale which mark 1 is given for option "strongly disagree" and 5 marks for option "strongly agree". Therefore, the Mean Difference $=0.35$ is equal to $7.0 \%$ improvement in the students' self-efficacy perceptions, in comparisons between STEM PjBL and conventional teaching methods.

Table 3. Mean score differences between experimental and control groups in the pre and post self-efficacy results

\begin{tabular}{lllll}
\hline Test & Group & N & Mean & SD \\
\hline Pre-Test & Experimental & 50 & 3.24 & 0.32 \\
& Conventional & 57 & 3.19 & 0.23 \\
Post-Test & Experimental & 50 & 3.53 & 0.25 \\
& Conventional & 57 & 3.18 & 0.22 \\
\hline
\end{tabular}

The research question can be converted to the following hypothesis:

H1a: There is no significant difference on post-test mean scores of self-efficacy scale in learning physics between students who follow STEM PjBL and conventional teaching method after the effect of pre-test mean scores is controlled.

Table 4 shows the univariate analysis of students' post-test score of self-efficacy scale across the various groups. The results exposed that there are significant differences between the experimental and control groups in the post self-efficacy scores with $F(1,101)=54.76$, Mean Square $(\mathrm{MS})=2.76$ and $p<.001$. Therefore, the statistical results required to reject the $\mathbf{H}_{1 \mathbf{a}}$ hypothesis. It means, there is significant difference on post-test mean scores of selfefficacy scale in learning physics between students who follow STEM PjBL and conventional teaching method after the effect of pre-test mean scores is controlled. 
Table 4. Univariate analysis of subjects' post-test score of Self-Efficacy in various groups

\begin{tabular}{|c|c|c|c|c|c|c|c|}
\hline Source & $\begin{array}{c}\text { Dependent Variable } \\
\text { Post-Self-Efficacy } \\
\text { Score }\end{array}$ & $\begin{array}{c}\text { Type III } \\
\text { SS }\end{array}$ & df & MS & $\mathbf{F}$ & $P$ value. & $\begin{array}{l}\text { Partial } \\
\text { Eta } \\
\text { Squared }\end{array}$ \\
\hline \multirow{5}{*}{ Corrected Model } & $\mathrm{ME}$ & $2.89 a$ & 5 & 0.58 & 6.25 & $<.001$ & 0.24 \\
\hline & VE & $4.92 \mathrm{~b}$ & 5 & 0.98 & 7.28 & $<.001$ & 0.27 \\
\hline & SP & $8.01 \mathrm{c}$ & 5 & 1.60 & 12.79 & $<.001$ & 0.39 \\
\hline & PS & $2.73 \mathrm{~d}$ & 5 & 0.55 & 5.13 & $<.001$ & 0.20 \\
\hline & Total & $3.94 \mathrm{e}$ & 5 & 0.79 & 15.62 & $<.001$ & 0.44 \\
\hline \multirow{5}{*}{ Intercept } & ME & 4.34 & 1 & 4.34 & 46.96 & $<.001$ & 0.32 \\
\hline & VE & 5.47 & 1 & 5.47 & 40.47 & $<.001$ & 0.29 \\
\hline & SP & 4.28 & 1 & 4.28 & 34.15 & $<.001$ & 0.25 \\
\hline & PS & 5.92 & 1 & 5.92 & 55.61 & $<.001$ & 0.36 \\
\hline & Total & 4.98 & 1 & 4.98 & 98.68 & $<.001$ & 0.49 \\
\hline \multirow{5}{*}{ GRP } & ME & 1.57 & 1 & 1.57 & 17.03 & $<.001$ & 0.14 \\
\hline & VE & 4.16 & 1 & 4.16 & 30.80 & $<.001$ & 0.23 \\
\hline & SP & 4.55 & 1 & 4.55 & 36.29 & $<.001$ & 0.26 \\
\hline & PS & 1.49 & 1 & 1.49 & 13.99 & $<.001$ & 0.12 \\
\hline & Total & 2.76 & 1 & 2.76 & 54.76 & $<.001$ & 0.35 \\
\hline \multirow{5}{*}{ Error } & ME & 9.34 & 101 & 0.09 & & & \\
\hline & VE & 13.65 & 101 & 0.14 & & & \\
\hline & SP & 12.66 & 101 & 0.13 & & & \\
\hline & PS & 10.76 & 101 & 0.11 & & & \\
\hline & Total & 5.10 & 101 & 0.05 & & & \\
\hline \multirow{5}{*}{ Total } & ME & 1210.02 & 107 & & & & \\
\hline & VE & 1199.22 & 107 & & & & \\
\hline & SP & 1268.69 & 107 & & & & \\
\hline & PS & 1168.54 & 107 & & & & \\
\hline & Total & 1204.18 & 107 & & & & \\
\hline \multirow{5}{*}{ Corrected Total } & ME & 12.23 & 106 & & & & \\
\hline & VE & 18.58 & 106 & & & & \\
\hline & SP & 20.68 & 106 & & & & \\
\hline & PS & 13.48 & 106 & & & & \\
\hline & Total & 9.04 & 106 & & & & \\
\hline
\end{tabular}

a. R Squared $=.236$ (Adjusted R Squared $=.198)$, b. $\mathrm{R}$ Squared $=.265$ (Adjusted R Squared $=.229$ ), c. $\mathrm{R}$ Squared $=.388$ (Adjusted $\mathrm{R}$ Squared $=.357)$, . $\mathrm{R}$ Squared $=.202($ Adjusted $\mathrm{R}$ Squared $=.163)$, e. $\mathrm{R}$ Squared $=$ .436 (Adjusted R Squared $=.408$ )

\section{DISCUSSIONS}

As shown in the results section, there was significant difference on the self-efficacy test mean scores between experimental group which followed STEM PjBL method and control group which followed the conventional teaching method. The finding is consistent with the (Pleiss et al., 2012) reporting that PjBL affects engineering student's self-efficacy particularly in the first-year of university courses. Liu et al. (2014), in the investigation of STEM selfefficacy and professional commitment to engineering among high school students, found that self-efficacy is an important factor for future job selection. The mean score for self-efficacy improved $11 \%$ (toward strongly agree) in comparison between STEM PjBL and conventional teaching methods.

The finding is in alignment with Cheng (2013) who tested the relationship between the self-efficacy and learning achievement within 252 undergraduate students from eight universities in Taiwan. Cheng (2013) stated that self-efficacy, explained only 9\% of the variance in learning achievement. It was mentioned that "the PjBL course is a cooperative course, and a student cannot finish the course by him/herself. Therefore, students do not think an individual's self-efficacy is the key factor to final learning achievement. Collective 
efficacy might be a more important factor for the PjBL course" (Cheng, 2013). Similar conclusion was stated by Schaffer et al. (2012) who investigated a total of 112 undergraduates from 34 teams in an in-service learning program who completed both pre and post project questionnaires. Overall, self-efficacy for "Cross-Disciplinary Learning in Project-Based Teams" increased across all respondents. However, research on relationship between selfefficacy and learning achievement reported was much higher than the results of this research as stated by (Hampton \& Mason, 2003). Project based learning (PjBL) was defined by Mills (2009) as a student-centered approach to learning in which students collaborate on sequential authentic tasks and develop a final project. In this research, the final projects were building a clock and a model crane which were different from Mills (2009) project for learning foreign language. However, both researches try to measure the effect of PjBL on the learners' selfefficacy. Both findings declare PjBL as an effective tool for students to improve their selfefficacy. The results of the current study also consistent with the previous studies showing that project based learning can directly improve student's self-efficacy (Cheng, 2013; Clark, 2014; Mills, 2009; Schaffer et al., 2012). Students with high self-efficacy for a particular task will be more likely to choose a path that requires the performance of particular task to persevere in the task over long periods of time and to persist in the face of difficulties (Bandura, 1977).

The origin of self-efficacy which come from cognitive theory (Bandura, 1977) specify that self-efficacy can have diverse effects in achievement settings (Schunk, 2012). Students with low self-efficacy for learning may avoid attempting tasks and doubt their capabilities when they encounter difficult problems (Schunk, 2012). Evidence strongly demonstrates the important role of self-efficacy which plays an influencing role in learning achievement (Cheng, 2013). On the other hand, self-efficacy plays a role to select a certain field of study in the future. For instance, Liu et al. (2014) showed that the STEM self-efficacy is an important factor that would affect girls' intentions in choosing the engineering profession.

The students in the STEM PjBL learnt and emitted like a scientist and engineers in the real-world. In line with situated learning theory, STEM PjBL positions learners in a simulated real-world context and helps them to develop ability like the scientists who use scientific reasoning for completing the task. Engineering design can become the context and the platform suitable for STEM learning when integrating STEM content (Kelley \& Knowles, 2016). In PjBL, students engage in meaningful problems related to the real-world which are similar to those activities that professional scientists and engineers get engaged in (Hsu et al., 2015).

The statistical results answered as "Yes" to the research question which stated that "is there a significant difference on the linear combination of post-test mean scores of selfefficacy in learning physics between students who follow STEM PjBL and conventional teaching method after the effect of mean scores of pre-test is controlled?". So, students who followed STEM PjBL method demonstrated slightly better self-efficacy to answer physics problems.

\section{CONCLUSIONS}

The findings of this study support using STEM PjBL method to improve students' selfefficacy for solving mechanics physics problems. In which, the results of the present study support the findings of several studies (Baran \& Maskan, 2010; Han et al., 2014; Olivarez, 2012). The PjBL approach can be very useful for high school students and physics teachers to solve real-world problems. STEM PjBL in high school increase students' self-efficacy to reach higher level of achievement that is an educational requirement for the future job 
opportunities. By combining STEM with PjBL teachers ensure maximum engagement of the students in the process of reached learning. The process of $\mathrm{PjBL}$ is student centred learning which gives more autonomy for the students to learn on their own. The STEM PjBL emphasizes to design and develop a product which requires students to undergo through STEM process. For example, if the students work alone the element of engineering is a challenging activity that requires the students to test and retest the product due to the nature of STEM PjBL process. This kind of activities requires the students to work in groups. Further research is needed that broadens the limited boundaries of research products. This study was limited to the "grade ten" high school students. Therefore, future research is needed to run STEM projects in the other high school levels (rather than grade ten) or other discipline (chemistry, mathematics, and biology) in order to analyze the effect of STEM PjBL on selfefficacy. Also, extending this research study to new populations will lead to a comprehensive underrating about the STEM PjBL effects in high school. So, the results would be more generalized.

\section{REFERENCES}

Akhavan, Ale Ebrahim, Fetrati, \& Pezeshkan. (2016). Major trends in knowledge management research: A bibliometric study. Scientometrics, 107(3), 1249-1264. doi:10.1007/s11192-016-1938-x

Amoozegar, Khodabandelou, \& Ale Ebrahim. (2018). Major trends in distance education research: A combination of bibliometric and thematic analyze. International Journal of Information Research and Review, 5(2), 5352-5359. doi:10.5281/zenodo.1239756

Bandura. (1977). Self-efficacy: Toward a unifying theory of behavioral change. Psychological Review, 84(2), 191-215. doi:10.1037/0033-295X.84.2.191

Bandura. (1986). Social foundations of thought and action: A social cognitive theory. Englewood Cliffs, NJ, US: Prentice-Hall, Inc.

Bandura. (1989). Social cognitive theory, six theories of child development: Revised formulations and current issues (Vol. 6, pp. 1-60): JAI Press, Greenwich.

Bandura. (1997). Self-efficacy: The exercise of control (1st ed.). New York: Macmillan.

Bandura, Barbaranelli, Caprara, \& Pastorelli. (2001). Self-efficacy beliefs as shapers of children's aspirations and career trajectories. Child development, 72(1), 187-206. doi:10.1111/1467-8624.00273

Baran, \& Maskan. (2010). The effect of project-based learning on pre-service physics teachers electrostatic achievements. Cypriot Journal of Educational Sciences, 5(4), 243-257.

Bardach, Gayer, Clinkinbeard, Zanjani, \& Watkins. (2010). The malleability of possible selves and expectations regarding aging. Educational Gerontology, 36(5), 407-424. doi:10.1080/03601270903212393

Betz, \& Hackett. (2006). Career self-efficacy theory: Back to the future. Journal of Career Assessment, 14(1), 3-11. doi:10.1177/1069072705281347

Blenkinsop, McCrone, Wade, \& Morris. (2006). How do young people make choices at 14 and 16. Retrieved from http://dera.ioe.ac.uk/id/eprint/6449

Blumenfeld, Soloway, Marx, Krajcik, Guzdial, \& Palincsar. (1991). Motivating project-based learning: Sustaining the doing, supporting the learning. Educational psychologist, 26(3-4), 369-398. doi:10.1080/00461520.1991.9653139

Bøe, Henriksen, Lyons, \& Schreiner. (2011). Participation in science and technology: Young people's achievement-related choices in late-modern societies. Studies in Science Education, 47(1), 37-72. doi:10.1080/03057267.2011.549621 
Britner, \& Pajares. (2006). Sources of science self-efficacy beliefs of middle school students. Journal of research in science teaching, 43(5), 485-499. doi:10.1002/tea.20131

Cervantes. (2013). The impact of project-based learning on mathematics and reading achievement of 7 th and 8th grade students in a south texas school district. (Doctor of Education), University of Texas, Austin. Retrieved from http://hdl.handle.net/1969.6/508

Chemers, Hu, \& Garcia. (2001). Academic self-efficacy and first year college student performance and adjustment. Journal of Educational Psychology, 93(1), 55-64. doi:10.1037/0022-0663.93.1.55

Clark. (2014). Self and collective efficacy perceptions during project-based learning implementation. (Doctor of Education in Leadership Studies), Ashland University, Ashland, $\mathrm{OH}, \quad$ USA. $\quad$ Retrieved from http://rave.ohiolink.edu/etdc/view?acc_num=ashland1397422154 (3671307)

Dalgety, \& Coll. (2006). Exploring first-year science students' chemistry self-efficacy. International journal of science and mathematics education, 4(1), 97-116. doi: 10.1007/s10763-005-1080-3

Darling-Hammond, Barron, Pearson, Schoenfeld, Stage, Zimmerman, . . . Tilson. (2008). Teaching for meaningful learning: A review of research on inquiry-based and cooperative learning Powerful learning: What we know about teaching for understanding: Jossey-Bass San Francisco, CA.

Dominguez, \& Jaime. (2010). Database design learning: A project-based approach organized through a course management system. Computers \& Education, 55(3), 1312-1320. doi:10.1016/j.compedu.2010.06.001

Doordinejad, \& Afshar. (2014). On the relationship between self-efficacy and english achievement among iranian third grade high school students. International Journal of Language Learning and Applied Linguistics World, 6(4), 461-470.

Erdogan, Navruz, Younes, \& Capraro. (2016). Viewing how stem project-based learning influences students' science achievement through the implementation lens: A latent growth modeling. Eurasia Journal of Mathematics, Science \& Technology Education, 12(8), 2139-2154. doi:10.12973/eurasia.2016.1294a

Fortus, Krajcik, Dershimer, Marx, \& Mamlok-Naaman. (2005). Design-based science and real-world problem-solving. Research report. International Journal of Science Education, 27(7), 855-879. doi:10.1080/09500690500038165

Frank, Lavy, \& Elata. (2003). Implementing the project-based learning approach in an academic engineering course. International Journal of Technology and Design Education, 13(3), 273-288. doi:10.1023/a:1026192113732

Gardiner. (2014, 3-5 April ). Professional education for the 21st century workforce. Paper presented at the Conference of the American Society for Engineering Education "Engineering Education: Industry Involvement and Interdisciplinary Trends", Bridgeport, Connecticut, U.S.A.

Hampton, \& Mason. (2003). Learning disabilities, gender, sources of efficacy, self-efficacy beliefs, and academic achievement in high school students. Journal of School Psychology, 41(2), 101-112. doi:10.1016/S0022-4405(03)00028-1

Han. (2017). Korean students' attitudes toward stem project-based learning and major selection. 17(2), 20xx. doi:10.12738/estp.2017.2.0264

Han, Capraro, \& Capraro. (2014). How science, technology, engineering, and mathematics (stem) project-based learning (pbl) affects high, middle, and low achievers differently: The impact of student factors on achievement. International Journal of Science and Mathematics Education, 1-25. doi:10.1007/s10763-014-9526-0 
Jamali, Md Zain, Samsudin, \& Ale Ebrahim. (2015). Publication trends in physics education: A bibliometric study. Journal of Educational Research, 35, 19-36. doi:10.5281/zenodo. 801889

Jamali, Nurulazam Md Zain, Samsudin, \& Ale Ebrahim. (2017). Self-efficacy, scientific reasoning, and learning achievement in the stem project-based learning literature. Journal of Nusantara Studies (JONUS), 2(2), 29-43. doi:10.6084/m9.figshare.5923585.v1

Jungert, Hesser, \& Träff. (2014). Contrasting two models of academic self-efficacy-domainspecific versus cross-domain-in children receiving and not receiving special instruction in mathematics. Scandinavian Journal of Psychology, 55, 440-447. doi:10.1111/sjop.12139

Kelly. (2015). Stem teacher efficacy in inverted classrooms. (Master of Science), North Carolina State University, Raleigh, NC. Retrieved from http://www.lib.ncsu.edu/resolver/1840.16/10632

Klassen. (2004). A cross-cultural investigation of the efficacy beliefs of south asian immigrant and anglo canadian nonimmigrant early adolescents. Journal of Educational Psychology, 96(4), 731-742. doi:10.1037/0022-0663.96.4.731

Lau, \& Roeser. (2002). Cognitive abilities and motivational processes in high school students' situational engagement and achievement in science. Educational Assessment, 8(2), 139-162.

Lent, Lopez, Brown, \& Gore. (1996). Latent structure of the sources of mathematics selfefficacy. Journal of Vocational Behavior, 49(3), 292-308. doi:10.1006/jvbe.1996.0045

Linnenbrink, \& Pintrich. (2003). The role of self-efficacy beliefs in student engagement and learning in the classroom. Reading \&Writing Quarterly, 19(2), 119-137. doi:10.1080/10573560308223

Lou, Liu, Shih, \& Tseng. (2011). The senior high school students' learning behavioral model of stem in pbl. International Journal of Technology and Design Education, 21(2), 161-183. doi:10.1007/s10798-010-9112-x

Lyons. (2005). The puzzle of falling enrolments in physics and chemistry courses: Putting some pieces together. Research in Science Education, 36(3), 285-311. doi:10.1007/s11165-005-9008-z

Marginson, Tytler, Freeman, \& Roberts. (2013). Stem: Country comparisons: International comparisons of science, technology, engineering and mathematics (stem) education. Final report. Retrieved from http://hdl.handle.net/10536/DRO/DU:30059041

Marks. (2001). Learned societies adapt to new publishing realities. A Century of Science Publishing, 91-96.

Olivarez. (2012). The impact of a stem program on academic achievement of eighth grade students in a south texas middle school. (Doctor of Education), Texas A \& M University, Corpus Christi, Texas. Retrieved from http://hdl.handle.net/1969.6/417 (3549798)

Pintrich, \& de Groot. (1990). Motivational and self-regulated learning components of classroom academic performance. Journal of Educational Psychology, 82(1), 33-40. doi:10.1037/0022-0663.82.1.33

Pleiss, Perry, \& Zastavker. (2012). Student self-efficacy in introductory project-based learning courses. Paper presented at the 42nd Annual Frontiers in Education Conference, FIE 2012, Seattle, WA.

Rooij. (2009). Scaffolding project-based learning with the project management body of knowledge (pmbok). Computers \& Education, 52(1), 210-219. doi:10.1016/j.compedu.2008.07.012 
Samsudin, Nurulazam Md Zain, Jamali, \& Ale Ebrahim. (2017). Physics achievement in stem pjbl: A gender study. The Asia Pacific Journal of Educators and Education, 32.

Sawtelle. (2011). A gender study investigating physics self-efficacy. (Doctor of Philosophy $(\mathrm{PhD})$ ), Florida International University, ProQuest LLC, Ann Arbor, MI. Retrieved from http://digitalcommons.fiu.edu/etd/512 (AAT 3502124)

Skaalvik, \& Skaalvik. (2007). Dimensions of teacher self-efficacy and relations with strain factors, perceived collective teacher efficacy, and teacher burnout. Journal of Educational Psychology, 99(3), 611-625. doi:10.1037/0022-0663.99.3.611

Tseng, Chang, Lou, \& Chen. (2013). Attitudes towards science, technology, engineering and mathematics (stem) in a project-based learning (pjbl) environment. International Journal of Technology and Design Education, 23(1), 87-102. doi:10.1007/s10798011-9160-X

Varon. (2015). Increasing $k-5$ students' non-cognitive skills through stem-integrated education. California State University, Northridge. Retrieved from http://hdl.handle.net/10211.3/159853

Veenman, Kenter, \& Post. (2000). Cooperative learning in dutch primary classrooms. Educational Studies, 26(3), 281-302. doi:10.1080/03055690050137114

Vega, Jiménez, \& Villalobos. (2013). A scalable and incremental project-based learning approach for cs1/cs2 courses. Education and Information Technologies, 18(2), 309329. doi:10.1007/s10639-012-9242-8

Wigfield. (1994). Expectancy-value theory of achievement motivation: A developmental perspective. Educational Psychology Review, 6(1), 49-78. doi:10.1007/BF02209024 